\title{
Change to a Skills-Based LLB Curriculum: \\ A Qualitative Study of Participants in a \\ Family Law Course
}

D Colgan*, W Domingo ${ }^{\star \star}$ and H Papacostantis ${ }^{\star \star \star}$

\section{P.E.R}

Pioneer in peer-reviewed, open access online law publications

Author

Desia Colgan

Wesah Domingo

Helen Papacostantis

Affiliation

University of Witwatersrand South Africa

Email

Desia.Colgan@wits.ac.za

Wesahl.Domingo@wits.ac.za

Helen.Papacostantis@wits.ac.za

Date published

8 December 2017

Editor Prof AA du Plessis

How to cite this article

Colgan D, Domingo W and

Papcostantis $\mathrm{H}$ " Change to a

Skills-Based LLB Curriculum:

A Qualitative Study of

Participants in a Family Law

Course" PER / PELJ 2017(20) -

DOI

http://dx.doi.org/10.17159/1727-

3781/2017/v20i0a1598

Copyright

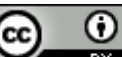

DOI

http://dx.doi.org/10.17159/1727-

3781/2017/v20i0a1598

\begin{abstract}
The transformation of educational institutions in South Africa led to institutions of higher learning rethinking their role in the new democratic era. This changed context called for wide-ranging curriculum reform within law schools and faculties. Curriculum changes were also impacted by the call from the profession to address the skills deficit of graduates, who were seen as lacking basic skills such as researching, reading and writing. The University of Witwatersrand's School of Law responded by making extensive changes to its existing curriculum during the period 2009-2012. This research sets out to examine the change to a skills-based LLB curriculum through the lens of the family law course implemented in 2012. The basis of the research is the argument that any educational change or reform should look beyond institutional change. It should also look at what has changed in practice with respect to the experiences of the individuals involved, at a personal level. This study focuses on the process of change, within the course as well as on an understanding of the phenomenology of change - how people in the family law course actually experience the change, in distinction from how the change was intended. The study adopted a mixed methods approach with a primarily qualitative focus, and was interested in understanding how the individuals affected were interpreting their experiences within the course. Through the use of questionnaires, interviews and focus groups the study revealed that for effective change the initiators need to understand the nature of change and acknowledge the views of all participants. This calls for the generation of shared meaning. The isolated tale of success of the family law course told in this study is not an indication that all of the courses impacted by change were successful. This study focuses on a single course, but it is the start of developing a deeper understanding of the process of change within a law school and to a law curriculum.
\end{abstract}

\section{Keywords}

Legal education; phenomenology of change; skills-based curriculum; shared meaning; qualitative and quantitative methods; standards for the bachelor of law. 


\section{Introduction}

With the call for the transformation of educational institutions in South Africa during the mid-1990s, institutions of higher learning were forced to examine their role and their contribution to the new democratic era. ${ }^{1}$ To this end the Education White Paper 3 provided an outline of the contribution expected of Higher Education Institutions toward social reconstruction and development. It highlighted the need to develop graduates who were capable of "contributing to economic and social development and democracy through learning and teaching, research and community engagement". ${ }^{2}$ Within law faculties or schools the move for change was influenced additionally by the call from the profession to create a more accessible law degree for all and to accommodate the diverse learners emerging from the then outcomes-based education system. ${ }^{3}$ All this whilst retaining the skills important to the profession. The ongoing influence of the profession on the LLB degree is evidenced through the comments made by practitioners and representatives of the law society, highlighted during the LLB Summit in May 2013 and through the subsequent review of the LLB degree. ${ }^{4}$ From as far back as 2005 complaints began to emerge regarding the quality and competence of law graduates. The then Judge President Ngoepe recognised that, even though it was important to "guard against generalisations", the complaints about the quality of younger practitioners could not be ignored. ${ }^{5}$ Likewise, when commenting on the skills required by law graduates, Swart pointed out that tertiary institutions were being forced to address the skills deficit inherited from primary and secondary schools.

* Desia Colgan. BProc (UZKN), LLB, MEd, PhD (WITS). Doctor, Lecturer, School of Law, University of the Witwatersrand, South Africa. E-mail: Desia.Colgan@wits.ac.za.

** Wesahl Domingo. BSocSc (UCT), LLB (UWC), LLM (Columbia Univ, NY), SJD (Univ of Wisconsin, Madison). Associate Professor of Law, School of Law, University of the Witwatersrand, South Africa. E-mail: Wesahl.Domingo@wits.ac.za.

*** Helen Papacostantis. BCom, LLB, LLM (WITS). Lecturer, School of Law, University of the Witwatersrand, South Africa. E-mail: Helen.Papacostantis@wits.ac.za. We acknowledge and thank Elizabeth Colgan for assisting with graphs.

1 Students, as the youth, must develop an understanding of their role in a postapartheid, democratic society. Jansen "Rethinking Education Policy-Making" 42.

2 Badat Challenges of Transformation 6; DoE Green Paper; Gen N 1196 in GG 18207 of 24 July 1997; and Higher Education Act 101 of 1997.

3 DoE Curriculum 2005 (C2005) was revised and streamlined in the form of the DoE Revised National Curriculum Statement (RNCS) implemented in 2008.

4 Van der Merwe 2007 April De Rebus 2; Thomaz 2010 http://www.engineeringnews.co.za/print-version/llb-degree-under-review-2010-01-15.

5 Dibetle 2007 https://mg.co.za/article/2007-11-14-quality-of-law-degrees-questioned; Godfrey "Law Professionals" 174. 
This resulted in their producing graduates who lacked basic skills such as reading, writing, research or numeracy. ${ }^{6}$

In response to this growing demand for change within law schools it was thought necessary to re-examine the existing LLB degree programme offered across all law faculties or schools in the country. The University of Witwatersrand's School of Law (hereinafter Wits Law School) responded to this call by making extensive changes to its curriculum during the period 2009-2012. ${ }^{7}$ The intention was not only to improve the substantive teaching of the basic principles of law but also to adapt to a more skills-based approach in line with the outcomes-based education model followed in high schools at that time. ${ }^{8}$ The context of such change thus presented an opportunity to carry out a research study that examined the shift toward a more skills-based approach in the LLB degree. This study was coupled with a study of the perceptions, attitudes and experiences toward the change of individuals involved in those specific skills-based courses. The research was carried out with the appropriate ethical clearance by academics based in the law school. At the outset it must be noted that the research was based on the change to the LLB curriculum in 2012 and was undertaken prior to the Fees must Fall campaign (hereinafter referred to as \#FeesMustFall) and the LLB Review. ${ }^{9}$

The research sets out to examine the change effected to the Wits Law School LLB curriculum specifically through the lens of the family law course offered in the year 2012. ${ }^{10}$ The significance of this year to the study is that this was the first time the family law course was offered as a skills-based course. It is a first-year course identified as one of the foundations upon which the key skills of law students are built. The research rested on the presumption that, when examining any educational change or reform, reflection should extend beyond studying the type of restructuring at institutional level. It should extend to what has actually changed in practice, incorporating the personal experiences of the individuals involved and affected by that change. Therefore this study focuses on the process of change within the course, as well as on building an understanding of the

6 Thomaz 2010 http://www.engineeringnews.co.za/print-version/llb-degree-underreview-2010-01-15. In the law school numeracy was not highlighted as a specific skill but was addressed in courses such as delict, family law, succession, contract and civil procedure.

$7 \quad$ Wits Law School Memorandum 2010 and Wits Law School Memorandum 2011.

8 Curriculum 2005 (C2005); Revised National Curriculum Statement (RNCS) implemented in 2008. Problems persisted and after further revisions in 2012-2014, Outcome-Based Education was ultimately scrapped.

9 Booysen Fees Must Fall.

10 This was the first year in which the skills-based family law course was offered. The next research project will focus on change post-2015 and will incorporate changes introduced after the 2015 LLB Review. 
phenomenology of change - how people in the family law course experienced the change, as distinct from how change was intended.

To do this, the study adopted a mixed methods approach with a primarily qualitative focus as the researchers were interested in understanding how the affected individuals were interpreting their experiences within the course. ${ }^{11}$ Initially the students registered in the course were identified as the principle research subjects. Through the use of pre- and post-assessment questionnaires and focus group interviews, student attitudes towards and experiences of the new skills-based course were examined. As the study evolved a realisation developed that the views of others, such as lecturers in the course, were equally pertinent, and hence their inclusion in the study.

This paper argues that in any change process the dynamic nature of change must be appreciated and understood. Change needs to be implemented at the appropriate level, in an appropriate way, taking into consideration the often variable human influence on that change. ${ }^{12}$ Change implemented without consideration of the people affected by it may result in resistance, or misunderstanding, or a total disregard of the change. The researchers questioned whether the primary focus of those who effected the change was structural, or whether consideration was taken of the individuals who would be affected by the change?

This article provides the context and history of the change process adopted with respect to the LLB degree, first introducing the rationale for changing the law degree in South Africa. Then, utilising the notion of change as a yardstick, we move into an examination of change from within the Wits Law School through lens of a specific course, the family law course. The role played by the principle driving agents is also highlighted, particularly with respect to the identification of important skills and skills-based courses. This is followed by the presentation of documentary evidence derived from the focus groups and interviews, which provided the data, the analysis of which leads to the findings with respect to the key objectives, purpose and implementation of a change to a skills-based curriculum. The final section of this contribution describes the analysis of the data and key findings, followed by recommendations and concluding statements.

\section{Definition and purpose of a skills-based course}

The debate that continues to impact on the development of the LLB degree has been ongoing for several decades and relates to the division between

\footnotetext{
Merriam Qualitative Research 5.

James "Psychodynamics of Educational Change" 49-50; Fullan New Meaning of Educational Change 43.
} 
academia and practice. ${ }^{13}$ Ultimately the question is what type of law graduate are we seeking to develop? Are law graduates to be trained in the practice of law via vocational training or are they to be trained foremost in academic legal discourse. As Campbell asks, "[s]hould the University law school train lawyers for practice or pursue a broader, academic legal education?"14 The challenge of delivering a legal education that caters to the discipline of law while also developing the general skills required in any profession is further exacerbated by the social challenges emerging from the South African education system as a whole, both pre- and postapartheid. ${ }^{15}$ Thus any debate on the different skills an LLB graduate requires both to pass the degree examinations and to ensure success in a legal career post degree must be contemplated against the backdrop of these multiple challenges. In the late 1990s criticism of the existing LLB degree became more vocal, this criticism, coupled with calls from the profession to increase the standard of legal education, ${ }^{16}$ led to the South African Law Deans' (SALDA) decision to focus on building an LLB degree which acts as a "[b]ridge between legal study and practice". ${ }^{17}$ It was at this point that the notion of integrating skills became a popular focus point.

In this context it was pertinent to establish which skills would be considered important for law graduates and for what purpose? It is generally accepted that a skills course work toward developing a holistically educated person, providing a well-rounded, broad education. ${ }^{18}$ Practitioners and academics are of the view that preparation for practice cannot be the sole focus of the curriculum, and that graduates should have an understanding of the social issues currently challenging society, including issues relating to gender, race, disability and people's ethical responsibilities. ${ }^{19}$ The standards for the bachelor of law degree speak of students who are socially conscious, enlightened citizens, with a profound understanding of the impact of the Constitution, and who strive for social justice in South Africa. ${ }^{20}$ This supports the Wits Law School's notion that skills training should not concentrate on producing a certain type of lawyer but rather on producing a graduate

13 See Campbell 2014 Stell LR 16; Church 1988 THRHR 153, 158; Kennedy $1982 \mathrm{~J}$ Legal Educ 591-615; Axam 2001 SAJHR 404.

14 Campbell 2014 Stell LR 16.

15 Campbell 2014 Stell LR 16. Highlighted by the 2015, 2016 \#FeesMustFall protests across South African universities, drawing attention to the importance of further "transformation" within institutions of higher learning. Booysen Fees Must Fall.

16 Council on Higher Education (CHE) also refers to the criticisms of the graduates.

17 Campbell 2014 Stell LR 18.

18 CHE Higher Education Qualifications Sub-Framework Bachelor of Laws (Draft Standards) General Characteristics 5; GN 928 in GG 30353 of 5 October 2007

19 Snyman-Van Deventer and Swanepoel 2013 Stell LR 511; Greenbaum 2012 De Jure 105; CHE Higher Education Qualifications Sub-Framework Bachelor of Laws (Draft Standards) Preamble.

20 CHE Higher Education Qualifications Sub-Framework Bachelor of Laws Preamble. 
equipped to take on any role within the legal profession in a democratic society. ${ }^{21}$ Such a graduate should be a reflection of a model citizen who is self-aware and can construct his or her understanding of the world. ${ }^{22}$

A number of skills have been identified as being essential to a law graduate in order that the graduate may successfully enter the practice of law or follow a chosen alternative path. When focusing on the development of necessary skills for a legal graduate, consideration also needs to be taken of the skills that can ensure a graduate's success, post qualification. ${ }^{23}$ In this context a well-rounded broad education refers to a graduate who not only successfully completes a degree but is also equipped to succeed in the employment market. Thus, in addition to acquiring the skills and knowledge necessary for legal practice, law graduates are also expected to acquire the universal skills set of other disciplines. This universal skills set is described in the HEQF as follows: "[a] Bachelor's degree has the primary purpose of providing well-rounded broad education that equips graduates with the knowledge base, theory and methodology of disciplines and enables them to demonstrate initiative and responsibility in an academic or professional context". ${ }^{24}$ The South African Qualifications Authority (SAQA) further states that not only should a law graduate have acquired the knowledge and content of law but they should also have "develop[ed] communication skills across all mediums, computer literacy and a basic competence in research". ${ }^{25}$

Consideration should also be taken of the role that law teachers play in ensuring that students currently entering law schools are not only exposed to a more skills-based approach but are also encouraged to pursue their own knowledge development. ${ }^{26}$ This changed learning environment means that law teachers will need to adjust their teaching approach and understand that students are not customers or consumers but are independent learners. This, according to Mbembe, calls for a move away from "quantitative measures of teaching excellence"27 toward the "free pursuit of knowledge". ${ }^{28}$ At the same time the socio-economic challenges facing the country and its people will undeniably influence the educational choices

21 Wits Law School Memorandum 2010 and Wits Law School Memorandum 2011.

22 Fruehwald 2013 http://ssrn.com/abstract=2243128.

23 SAQA 2015 http://regqs.saqa.org.za/viewQualification.php?id=22993.

24 GN 928 in GG 30353 of 5 October 2007; Snyman-Van Deventer and Swanepoel 2013 Stell LR 511 .

25 SAQA 2015 http://regqs.saqa.org.za/viewQualification.php?id=22993; Also Campbell 2014 Stell LR 18-19. This includes the "universal" skills set for other disciplines.

26 Mbembe 2015 http://wiser.wits.ac.za/content/achille-mbembe-decolonizingknowledge-and-question-archive-12054 5.

27 Mbembe 2015 http://wiser.wits.ac.za/content/achille-mbembe-decolonizingknowledge-and-question-archive-12054 6.

28 Mbembe $2015 \mathrm{http} / / /$ wiser.wits.ac.za/content/achille-mbembe-decolonizingknowledge-and-question-archive-12054 5. 
made and the direction taken. While it may be very noble to aspire to the "perfect" all round curriculum, the reality is that a curriculum at a tertiary institution must also accommodate the diverse backgrounds of each student. With a diverse body of students, an institution and its legal educators will need to adapt to a range of student needs and learning styles in order to better develop student understanding. ${ }^{29}$ Some students will be more equipped than others and will thus progress more ably through a degree and achieve the desired outcomes. ${ }^{30}$

\section{Changing environment}

Although it is apparent that change at this time was necessary, even inevitable, in the light of the changing socio-political context, the question remains what is the nature of the change adopted and how will it proceed into the future? Initiators of change often overlook the simple fact that change is dynamic and can misunderstand this in their haste to be "seen to change". ${ }^{31}$ This raises the concern that decisions are often made and driven from the top, by a few, and that such decisions may not always take into account the voices of the many who may be impacted by the change. ${ }^{32}$ It is important when planning for educational change that the initiators should think beyond easy to employ one-off, linear strategies that focus on changing materials or the curriculum, and should instead take the bigger picture into consideration. ${ }^{33}$ Any innovative process that fails to consider issues such as the participants' personal social development goals and "felt needs" may ultimately fail to reach the intended objectives. ${ }^{34}$

This article argues that initiators of change can and do vastly underestimate both what change is and the factors involved. This is not only about the concrete, formal changes - policy change, or a change in curriculum — but the values and belief systems of the individuals within institutions who are the participants in the change. ${ }^{35}$ Initiators need to consider the broader context, to be aware that if change is initiated at management level it will have implications for people further down the line, for implementers and

29 Over the last five years $75-80 \%$ of students registered for the LLB degree at Wits University have been black, coloured and Indian. The majority of them have been black.

30 Schools influence learners into a certain way of thinking. Much focus is placed on filling seats and ensuring a physical presence instead of fostering an enthusiasm to learn and a will to challenge. We, the authors, are concerned that this situation prevails at universities too. Pateman $1980 \mathrm{~J}$ Philos Educ 142.

31 Fullan New Meaning of Educational Change 67.

32 Sugrue Future of Educational Change 5; Fullan New Meaning of Educational Change; Colgan Perceptions of Democracy Education 10.

33 Sugrue Future of Educational Change; Morrison Management Theories 13-15.

34 Morrison Management Theories 13-15.

35 Morrison Management Theories 13-15; Colgan Perceptions of Democracy Education 10. 
students alike. When dealing with change it is important to accept that we are faced with a shifting target that is being played out in social settings, amongst groups of individuals, all with varying perceptions, values, attitudes and opinions toward the change. ${ }^{36}$ To address the multiple understandings, or misunderstandings, and interpretations of a situation, solutions must come through the development of shared meaning amongst key role players. The reality is that any innovation cannot be assimilated unless its meaning is shared. ${ }^{37}$ Shared meaning in this context, and for the researchers, refers to acknowledging and recognising that students and lecturers are participants in change. This means that they are an integral part of the planning process, not the end goal. Arguing for shared meaning is the equivalent of arguing for the inclusion of students and lecturers from inception of the planning for change. ${ }^{38}$

If change is introduced in such a way that the subjective reality of participants, ${ }^{39}$ such as lecturers or students, is overlooked then it may be met with some resistance, particularly if the change is seen as imposed from above or from outside. Change is uncomfortable at a personal and collective level and real change involves a shift through levels of uncertainty and ambivalence. Such a shift, from the known to the unknown, brings with it feelings of anxiety and stress. ${ }^{40}$ This is even more of a factor where people's "occupational identity" is under threat. ${ }^{41}$ Where a person has developed experience in handling a job, over a period of time, and has "accumulated wisdom" with respect to that job, the introduction of change "threatens to invalidate" this accumulated experience. ${ }^{42}$ When a person's identity, belief or value system is threatened they may react by resisting or blocking change in a variety of ways.

Therefore, a person's perception or experience of change, their subjective reality, impacts on their response to it. As Morrison points out, "[c]hange changes people, but people change change". ${ }^{43}$ Not all participants will necessarily resist or block the change. Some may simply fail to assimilate it. In this instance the participants may act as if they have changed. They may use correct terminology and new materials, and may even imitate certain behaviour but the deeper purpose of the change may not have been

\footnotetext{
Morrison Management Theories 15; Fullan New Meaning of Educational Change 5. Marris Loss and Change 121.

Senge Fifth Discipline. Senge speaks of a process different from strategies such as developing vision statements. Shared meaning is a deeper process involving active listening, reflection, trust and mutual understanding.

39 Subjective reality refers to the beliefs, perceptions, experiences of individuals.

40 Fullan New Meaning of Educational Change 31-35.

41 Marris Loss and Change 16.

42 King "Involvement in Innovation" 623; Fullan New Meaning of Educational Change 36; Morrison Management Theories.

43 Morrison Management Theories 15.
} 
understood. Fullan refers to these behaviours as forms of non-change: false clarity or painful unclarity. People display false clarity when they assimilate only "the superficial trappings of the new behaviour or practice". ${ }^{44}$ They may think they have changed but are simply paying lip service to the change. The second form of non-change is painful unclarity. If innovations are introduced without providing the clarity needed to support change at a subjective level, the participants may never fully understand the principle or rationale for the change. ${ }^{45}$

Thus, if what people do and think are essential components for the successful implementation of change then providing clear statements and guidelines at the commencement of a change programme will not be enough. Change is a process, not an event. ${ }^{46}$ No matter how necessary and well-intentioned a new programme or policy may be it must not be forgotten that "[c]hange works or does not work on the basis of individual or collective responses to it". ${ }^{47}$ As Fullan states, all-encompassing change requires an understanding of the phenomenology of change, and ignoring this lies at the heart of the spectacular lack of success of most social reform. ${ }^{48}$

\section{Skills-based curriculum}

Prior to 2008 there was talk of curriculum change so that the students coming out of an outcomes-based education system would be able to integrate into a tertiary level of education. The review of the Wits Law School curriculum started in earnest in 2009 with the School's Curriculum Committee ${ }^{49}$ The Committee was tasked with introducing more skills-based teaching into the curriculum together with changing the course offerings by introducing some new courses and removing others. The Wits Law School offered the following LLB degree streams: LF004 - a 4-year undergraduate LLB degree; LF006 - a 2-year postgraduate LLB degree with an undergraduate major in law; and LF007 - a 3-year postgraduate LLB degree with no previous legal study. After the completion of this study, the Wits Law School in 2015 implemented a further change in that it no longer offered the 4-year undergraduate degree. In its place the School offered the LF006 and LF007 streams. In spite of this, the curriculum was not changed and the

44 Fullan New Meaning of Educational Change 35, 70.

45 James "Psychodynamics of Educational Change" 61; Fullan New Meaning of Educational Change 35, 40.

46 Hall and Loucks Innovation Configurations 3; Fullan New Meaning of Educational Change 130.

47 Hargreaves 2005 Teaching and Teacher Education 981; Fullan New Meaning of Educational Change 46.

48 Fullan New Meaning of Educational Change 4.

49 The committee was comprised of six members and included professors and lecturers. 
identified skills courses remained substantially the same. The value of the research reported on here from therefore remains significant. ${ }^{50}$

In 2009, the Committee noted that the vast majority of students entering the LLB program at the Wits Law School did so straight out of grade $12 .{ }^{51}$ Some students might have a good skills set whereas others might be underprepared. Furthermore, the Committee noted that many students had English as their third or fourth language. ${ }^{52}$ According to the Committee many academic staff members indicated that they spent an inordinate amount of time reviewing their students' work from a grammatical or structural point of view. ${ }^{53}$ The Committee therefore identified a core set of skills that should be taught in specific courses throughout the LLB. In order to maximise skills transfer, it was decided to embed each particular set of skills in a substantive course, as opposed to having stand-alone skills courses. The idea was to build on the skills in each successive year of study. The following courses, all of which are compulsory and a year in duration, were identified as skills courses. ${ }^{54}$

a) Family law (first year): skill set - working with legal authority, that is reading and writing.

b) Contract Law (second year) - legal problem solving and legal reasoning.

c) Jurisprudence (second year) - argumentation, critical thinking and essay writing.

d) Civil Procedure (third year) - legal drafting.

e) Practical Legal Studies (fourth year) - Comprehensive legal practical skills (interviewing, statement taking, professional management,

50 In the LLB review report the panel contextualised the change in 2012 and stated,"[t]he programme that was then designed, complied with the demand for logical sequencing and increasing complexity of module content and assessment". CHE National Review of LLB Programme 6.

51 Wits Law School Memorandum 20111.

52 Wits Law School Memorandum 20111.

53 Wits Law School Memorandum 20111. The law school was commended for having a Writing Centre with two permanent staff dedicated to the students in the Law School. The LLB review report stated, "[i]t provides 'embedded' writing development support across the curriculum in collaboration with the lecturers, individual writing support to students and support to enhance legal argumentation". CHE National Review of LLB Programme 11.

54 Wits Law School Memorandum 20112 . The various skills courses included activities where students were encouraged to debate and argue legal concepts. In the family law course, student activities provided opportunities for students to brainstorm and mind-map ideas, discuss and debate complex issues which involved active listening, and participate in spot quizzes. 
professional ethics, trial preparation, trial advocacy in a live client situation).

f) Independent research report (fourth year elective) - comprehensive legal research skills (ability to frame, analyse and respond to a particular research question). ${ }^{55}$

The designation of the above courses as "skills courses" was not intended to convey the impression that skills are not taught in other courses in the LLB. ${ }^{56}$ They are, however, the vehicles in which these skills are explicitly taught as well as assessed as among the module outcomes. ${ }^{57}$ The implications for other courses in the LLB programme are two-fold: Firstly, teaching in the substantive courses must be aligned both with content and with the sequencing of the skills courses. ${ }^{58}$ It would thus be inappropriate for a first-year course to expect students to solve complicated legal problems, or for a second-year course to expect students to undertake legal drafting. ${ }^{59}$ The expectations around legal problem solving and legal drafting in "non-skills courses" would be based on what has been taught in Law of Contracts and Civil Procedure respectively. Secondly, a policy decision was taken to concentrate intensive writing assignments in the skills courses, which would require the coordinators in the courses to adopt different and innovative forms of assessment. ${ }^{60}$ In this regard it is important to note that most of the compulsory courses in the LLB have in the range of 600-700 students in the first and second years, and 300-400 students in the final two years. ${ }^{61}$

It was agreed by the Committee that the skill set should include the following general components: 62

a) Legal research capabilities.

55 This course has to date not been implemented as a compulsory course. Due to a lack of capacity, the feasibility of designating this course as compulsory was called into question.

56 Wits Law School Memorandum 20112.

57 Wits Law School Memorandum 20112.

$58 \quad$ Wits Law School Memorandum 20112.

59 Wits Law School Memorandum 20112.

60 Wits Law School Memorandum 2011 2. The LLB review report supported this approach saying that the writing-intensive modules called on students "to do more writing assignments and exercises than in other modules". CHE National Review of LLB Programme 16. An example of the type of assessment in the family law course would be to carry out an analysis of an academic article and a case-analysis, starting with very simple questions and moving on to more complex questions.

61 Wits Law School Memorandum 20112.

62 Wits Law School Memorandum 20102. 
b) Legal analysis such as how to read judgments, how to read legislation, how to read contracts and how to read academic writing.

c) Elementary legal writing capabilities, including legal essay writing and exam writing, legal correspondence, research memoranda or legal opinions and basic drafting of court documents.

d) Argumentation skills, both oral and written.

e) Communication skills in writing and in person.

f) Comprehensive legal practical skills.

The lecturers teaching these subjects would have the facilities, support ${ }^{63}$ and time allocated to their work in order that they could enhance the LLB in this way. ${ }^{64}$ The broad objective of the skills-based curriculum was to create a syllabus which taught students basic substantive principles of law, whilst teaching students how to think, write, research, communicate and interact with people as legal actors. ${ }^{65}$ The idea was to create legal thinkers who could contribute to the practice, development and creation of the law. The skills training of law students is not about training candidate attorneys. The LLB degree is a liberal education in law, rather than vocational training in law. The Committee highlighted that skills training is not focussed on only one part of the profession but focusses rather on equipping students with the legal skills to take on any number of legal roles, including the roles of academics, activists, law-makers, participants in the criminal justice system and, of course, members of the bar and side bar. ${ }^{66} \mathrm{~A}$ fundamental aim of the skills curriculum is to teach students to teach themselves. The revised curriculum cut down on "the substantive training and injected the quotient of skills teaching so that students would be equipped with the tools to research substantive areas of law which may not be covered in a particular course". ${ }^{67}$

With regard to the commitment of academic staff to the teaching of skills, lecturers were asked to engage in skills training before redesigning their syllabi. The Committee agreed that lecturers who teach skills would receive training regarding the integration of skills teaching into their course subject matter, and that they would be allocated appropriate time in their workload

63 The Writing Centre in the School of Law is staffed by qualified writing and language experts. These experts collaborate with lecturers in the skills courses, but work closely with all the lecturers who teach in the first-year courses.

64 Wits Law School Memorandum 20102.

65 Wits Law School Memorandum 20104.

66 Wits Law School Memorandum 20105

67 Wits Law School Memorandum 20105. 
for this endeavour. ${ }^{68}$ The underlying theory was that the teaching of skills is not about taking on more work but about reducing the overall workload of the academics by enabling students to teach themselves. Lecturers were not to teach every principle of law. ${ }^{69}$ The Committee decided that a person would be appointed to be responsible for the Skills Teaching Portfolio. ${ }^{70}$ This would be an academic trained in skills development, language, reading, writing and argumentation skills. It was also decided that the school would develop a small committee of experts with people who had specialised in the area of legal education. ${ }^{71}$

\section{Methodology - research design}

This was a case study relying on both qualitative and quantitative research methods. The purpose of selecting both methodological approaches lay in the fact that pre- and post-assessment questionnaires could be appropriately used to gather data from a large number of student participants. However, to explore the reasons why certain perceptions or attitudes were held, focus group discussions and interviews were identified as more suitable for the purposes of the study. The family law course was selected as ideal for a case study as it is a skills-based course running over a full year. It has three lectures per week with additional tutorials. There are four family law classes. Each class was allocated a research and teaching assistant (RTA) who assisted with the tutorials and the marking of the tutorial exercises. The course consisted of the following assessments: case summary (10\%), June exam (30\%), essay (30\%) and take-home exam $(30 \%)$.

Our sample was made up of the students registered for the family law course and three lecturers in the course. The student participants consisted of first- and second-year students, repeat students and postgraduates. The student participants were asked to complete two questionnaires: a pre- and a post-assessment questionnaire. Much of the pre-questionnaire sought to establish student demographics in the course. Additional questions asked students about their expectations of the course and the key skills. The prequestionnaire was administered early in the semester, prior to any assessments being performed. The second was administered in the second semester, after the students had completed two assessments, one of which was a June exam. This questionnaire went beyond determining demographics and looked at student expectations mid-course of lecturers, themselves and the course. These questionnaires were developed in 2012 prior to the LLB review and to experiencing the challenges currently facing

Wits Law School Memorandum 2010 6,15.

Wits Law School Memorandum 20106.

Wits Law School Memorandum 201015.

Wits Law School Memorandum 201015. 
Universities such as the \#FeesMustFall and institutional decolonisation campaigns. ${ }^{72}$

600 pre-questionnaires were distributed in the first semester and 310 were returned. 400 post-questionnaires were distributed in second semester and 226 were returned. ${ }^{73}$ Certain limitations are noted regarding data collection through questionnaires such as the following: a number of students failed to return the questionnaires; the blank questionnaires were returned; some responses were deliberately spoiled; and not all questionnaires were distributed in the second half of the year.

Specific questions were selected for the purposes of this study and were coded and analysed through identifying key themes. The demographics of the student body were determined in terms of age, gender, home language, level of degree, and support system - financial and personal. To address some of the issues raised in the questionnaires, three focus group discussions were held with a sample of family law students who volunteered to participate. These discussion groups were made up of 6-8 participants, both male and female. The two focus group moderators were selected because they were seen as impartial, having no relationship with the course or with the students in the course. The discussions were tape recorded and then later transcribed. The initial questions asked of the focus group were open-ended, aimed at establishing a rapport with the student participants. The next phase of questions explored student experiences, attitudes and perceptions toward the course, the lectures, and themselves in the course. The last part of the discussion explored more specific reflections on academic legal writing and student perceptions after their June exam.

Additional data were gathered through one-on-one interviews with three lecturers in the course and through documentary evidence found in memos, records of meetings and email correspondence. Also included in the study was an in-depth review of the course conducted by a family law expert from the University of Cape Town. The review was conducted at the request of the family law lecturers.

\section{Findings and analysis}

The first questionnaire was administered soon after the commencement of the course. As the students had attended three to four weeks of lectures prior to responding to the questionnaire, they were aware that the course was a skills-based course. The pre-questionnaire elicited data about the demographic nature of the student participants. In the post-questionnaire student perceptions and experiences were explored in more depth.

\footnotetext{
72 Booysen Fees Must Fall.

73 Not all lecturers were able to distribute the questionnaires timeously.
} 
This section of the paper initially presents the demographics identified as being significant to the study. This presentation is followed by an analysis of the findings derived from both the questionnaires, the focus group discussions and the interviews with lecturers in the course. We conclude with a summary of the findings.

\subsection{Student demographics}

Of the 310 respondents to the pre-questionnaire $70 \%$ were in the $18-20$ age group, $17 \%$ were in the 21-24 age group and those in the 25-50 group account for $10 \%$. The group consisted of 177 females and 133 males. Figure 1 indicates the number of undergraduate students in the course, measured against their age-group and the school attended prior to University.

Figure 2 is a combination of the total number of students registered in the course, including their age and school attendance, prior to University. Figures 1 and 2 indicate that the majority of the students in the sample were 19 years of age and attended government schools (50). 40 members of this group had registered for an undergraduate LLB and 10 had registered for either a BA/LLB or a BCom/LLB. In the 18-20 age group the majority of the students had attended government schools (115), with the remaining 102 being from IEB (90) and other schools/institutions (12).

Figure 1: Number of students versus age enrolled in an undergraduate LLB degree and schools attended prior to university.

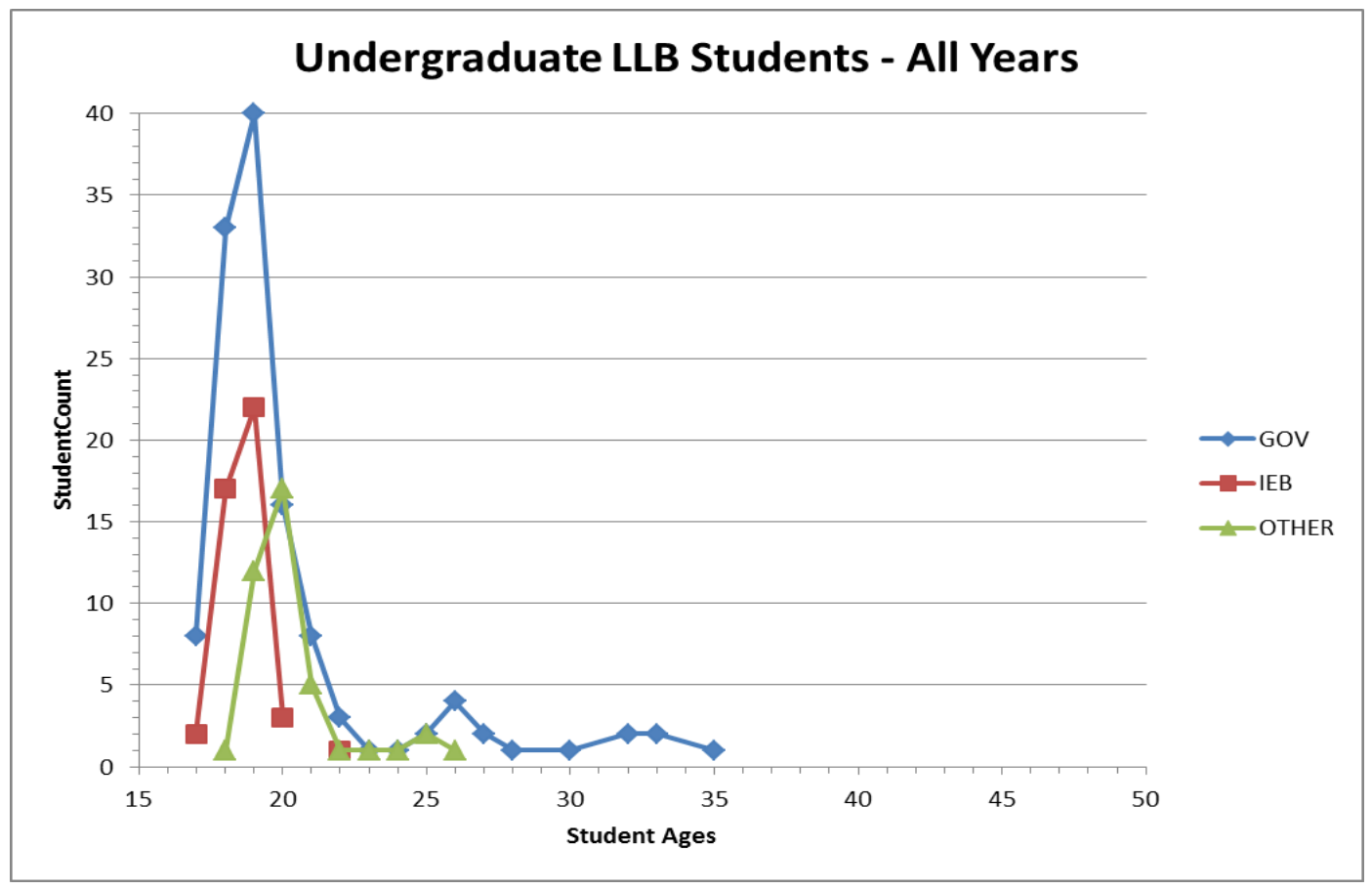


Figure 2: Number of students versus age enrolled in all degrees and different schools attended prior to university.

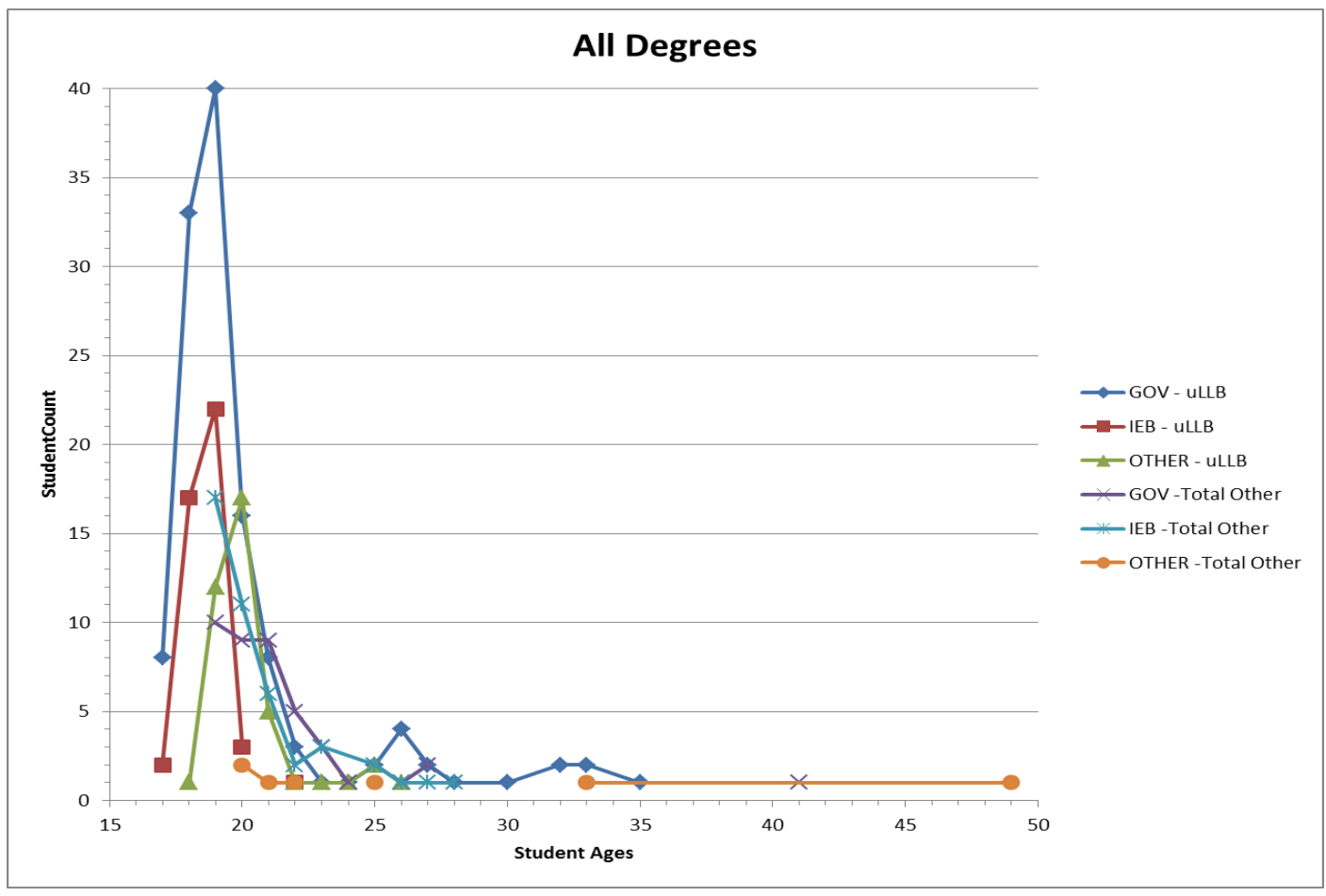

Figures 1 and 2 clearly indicate that the majority of the students in the sample group were aged between 18 and 20 years, with most being recent school leavers. This group, recently schooled, would have been exposed to both $\mathrm{C} 2005$ and the RNCS, thus raising additional concerns with respect to the quality and reliability of their matric results. ${ }^{74}$ Older students registered in the course made up 20,4\%, with most falling between the ages of 33 and 50 , and being postgraduate students. Thus the majority of the students in family law in 2012 were first-time university students.

74 Due to the phasing out the differentiation between subjects at higher and standard grades; also because of the use of standardisation. It is argued that standardisation impacts on the reliability of the matric results. See Mouton, Louw and Strydom 2012 IBERJ 1218. 
Figure 3: Frequency of undergraduates and postgraduates in each language group. The largest group is English speakers who are undergraduate students (110).

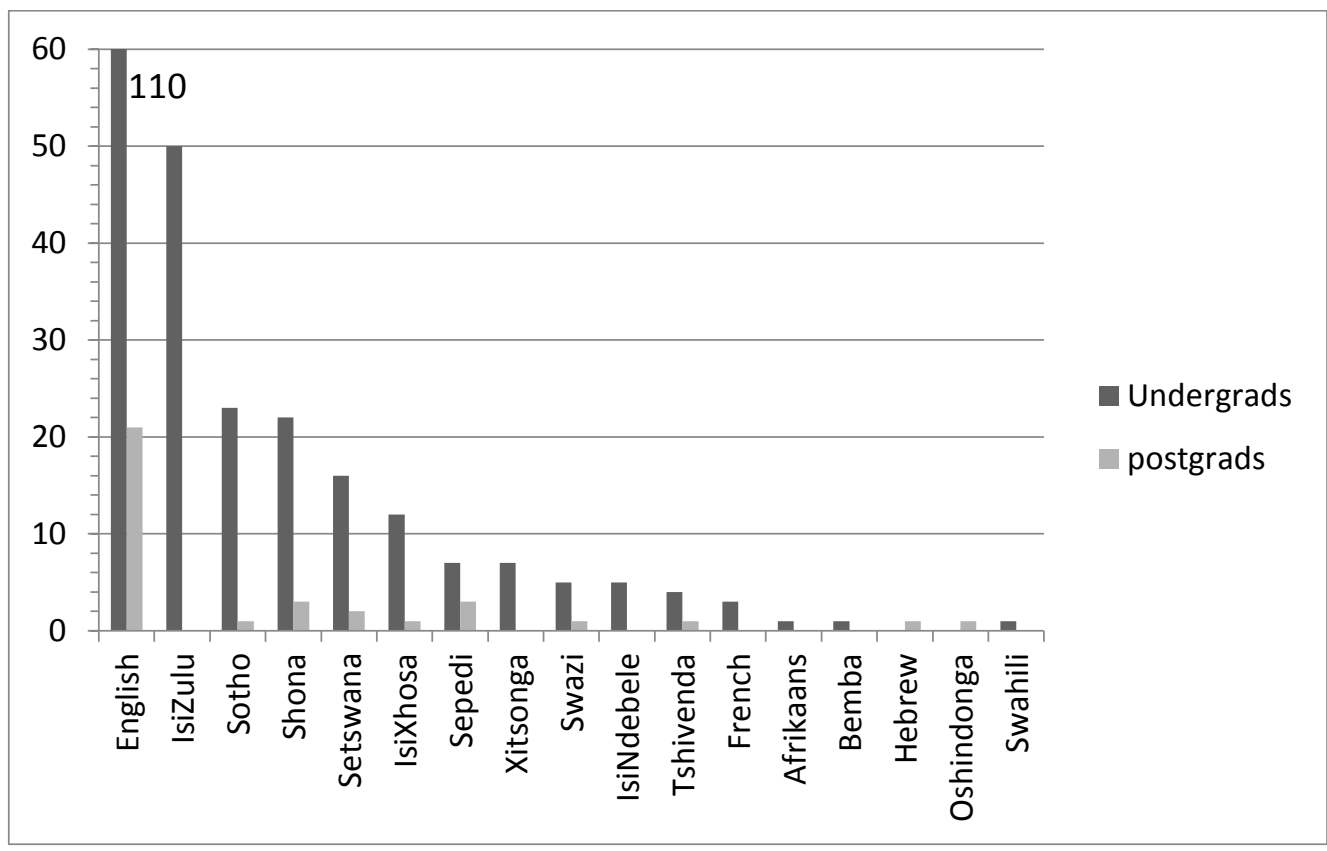

In Figure 3 above it may be seen that the largest group of students indicated English as their home language (43\%), with IsiZulu (16\%) as the next language group. Most of the students in both groups had registered for an undergraduate LLB. Students in the IsiZulu group students had registered for the undergraduate LLB only. There were 110 undergraduate students and 21 postgraduate students in the English group. Both Sotho and Shona each made up $8 \%$ of the cohort, Setswana made up 6\% and IsiXhosa and Sepedi were each 4\%. Languages such as Tshivenda, Swazi, Tsonga, and IsiNdebele accounted for about $2 \%$ of the cohort each, and all other languages for $1 \%$ or less. In all the language groups the number of postgraduate students was significantly lower than the number of undergraduates, as indicated in Figure 3.

Figure 4 refers to student accommodation. 53\% of the participants were living at home and the remainder (47\%) were living either in student lodgings or, as described by students, 'digs' (20\%), on campus (14,5\%), or in other accommodation (12,5\%).

Figures 4 and 5 divide the students into two groups. Figure 4 shows firstyear students who were the first in their families to attend university (firstgeneration students) and Figure 5 shows first-year LLB students members of whose families had previously attended university (second-generation students). $44 \%$ of the first-generation students and $43 \%$ of the secondgeneration students were living at home. Students staying on campus also showed similar percentages in both groups $-22 \%$ first-generation students and approx. 20\% second-generation. Slight differences existed between the 
first- and second-generation students who stayed in student lodgings (or off campus) $-22 \%$ and $28 \%$ respectively, with $6 \%$ fewer off campus in the first-generation group. Slight differences also appeared between first- and second-generation students who stayed in other accommodation $-12 \%$ and $9 \%$ respectively, with $3 \%$ more in the first-generation group.

The students in both groups were broadly similar in their age distribution and their types of accommodation, although the percentage of firstgeneration students in their $26^{\text {th }}$ year of age staying at home showed a slight increase $(5 \%)$. Of the first-generation students, $16 \%$ in their $18^{\text {th }}$ year and $10 \%$ in their $19^{\text {th }}$ year were staying at home. The opposite was true for the second-generation group, where $11 \%$ of the 18 year-olds and $15 \%$ of the 19 year-olds were staying at home.

The students were asked who was paying for their studies at University. The majority (54\%) indicated that relatives were paying for their studies, but did not specify the type of relationship (parents, siblings or uncles/aunts). $20 \%$ said they had received bursaries in 2012. Again, students were not asked to specify the bursary type. $17 \%$ indicated that they were self-funded and $8 \%$ did not specify how they were being funded and were marked as "other".

Figure 4: First-year LLB students: first in family to attend university, age and accommodation whilst studying.

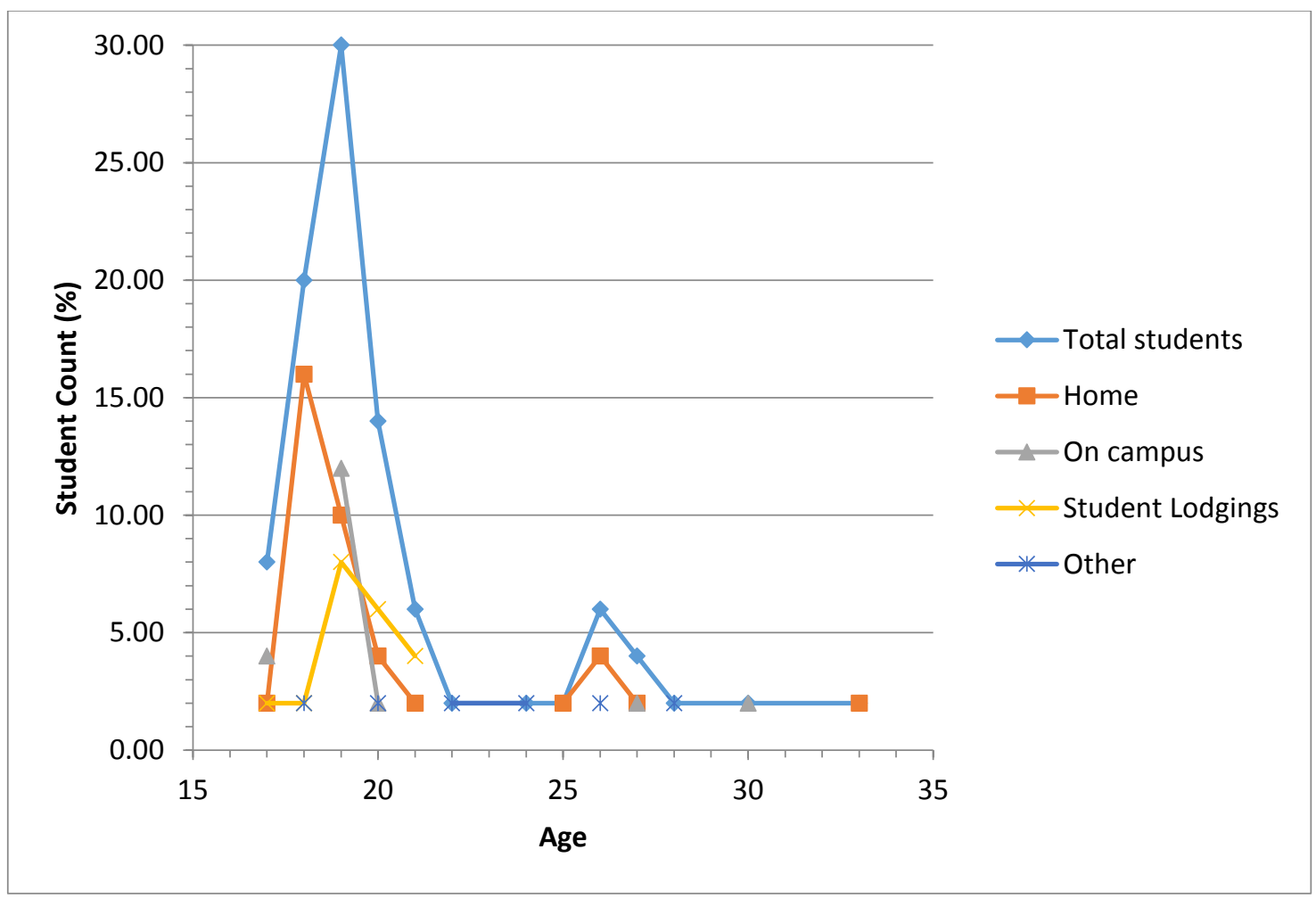


Figure 5: First-year LLB students - family had attended university before, age and accommodation whilst studying.

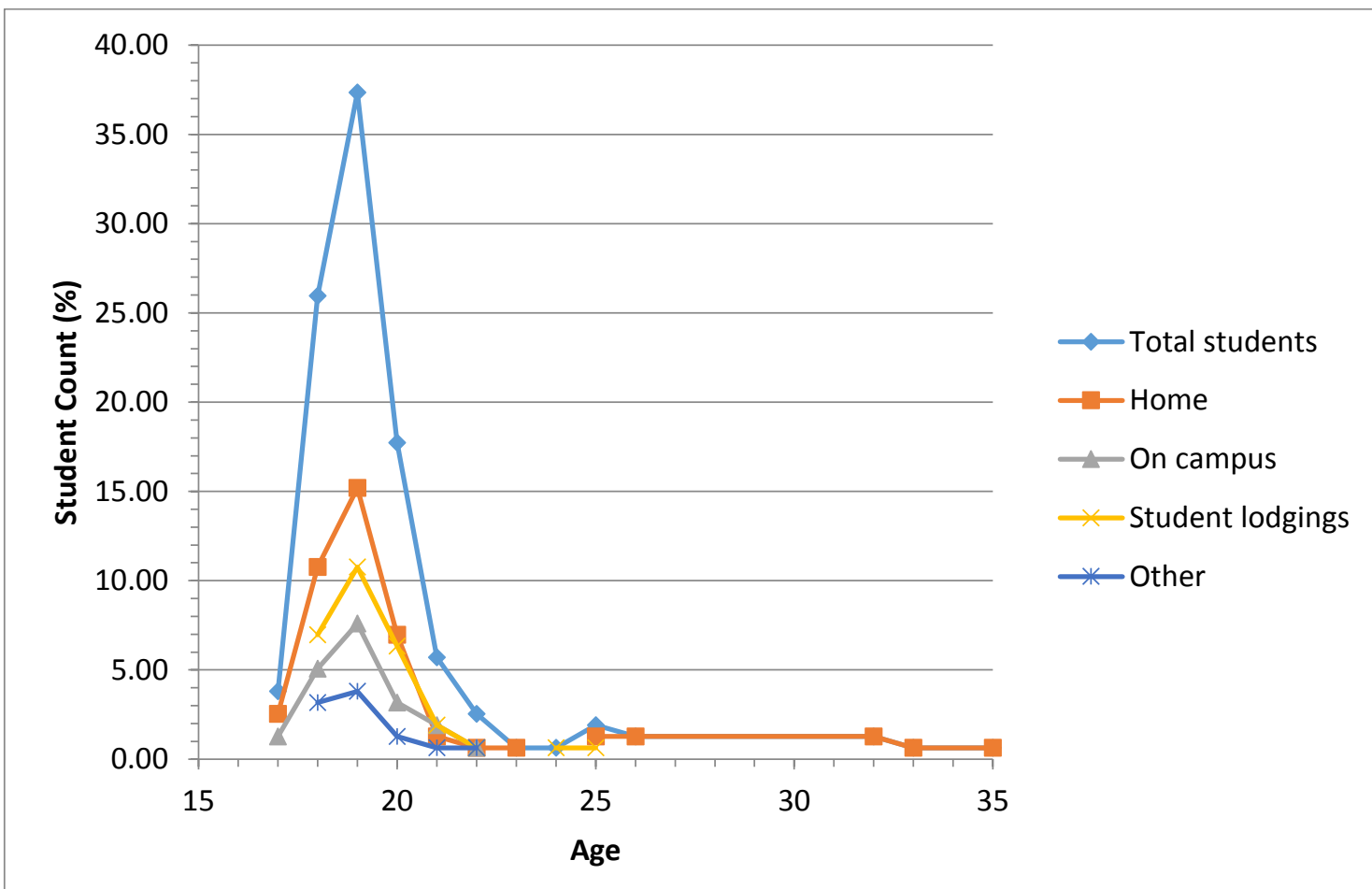

\subsection{Focus groups and interviews}

The various instruments used provided a body of data that was subsequently analysed and three key themes were revealed:

a) Transition into law school (i) for school leavers, and (ii) for postgraduate students;

b) Specific skills identified by students;

c) Perceptions and attitudes towards the course: (i) the student perspective, and (ii) the lecturer perspective.

\subsubsection{Theme 1: Transition into law school}

Both the postgraduate students and the undergraduate students participated in the focus group discussions, from which it emerged that the experiences they had encountered on transitioning into law school differed between the two groups. These differences were due to the fact that undergraduate students were entering a university environment for the first time. The postgraduate students had already been part of a University environment but were entering the law school environment for the first time. 
Because their transition into law school differed, this will be discussed before their shared experience of the family law course is looked at.

\subsubsection{School leavers}

As indicated in figures 1 and 2, fewer than three quarters of the students are within the age group 18-20 years. These are mostly undergraduates and school leavers, but there is a small number of postgraduate students. ${ }^{75}$

When the undergraduate students were asked about their transition from high school to university a large number said they found the transition difficult. They said that they felt unprepared on entering the university environment and felt various forms of uncertainty related to academic culture shock, identity shock and feeling like an outsider, and feeling lost and unsupported. All of these impressions contributed to an overall sense of anomie. ${ }^{76}$

\subsection{Adapting to a different academic culture}

Many student respondents said they struggled to make the initial transition from the familiar academic culture at high school to the uncertain, unfamiliar culture within a university. A few said that for them the transition was difficult because at high school, where there were smaller classes, they were academic achievers, whereas at university, where there were larger classes, they simply became average students. They also said that high school ill-prepared them for a law degree and that success in their first year depended on the subjects chosen at school. The respondents said that a noticeably challenging aspect of university academic culture was the expectation that students would take responsibility for their own learning, coupled with a larger workload. At a tertiary level there is an expectation that students are independent learners motivated and able to find access resources for themselves. This was different from the culture of spoonfeeding that many had experienced at high school, where there was also less work. It was obvious from both the responses to the questionnaires and the focus group discussions that some students were more able to adjust to these academic demands than others. This was highlighted by the comments of the following first year undergraduate students:

You get here and work like nobody cares, midnight sleeping, really late, working, working, asking questions and trying to really understand but then you are so average. It comes with the competition, not only in law school but university at large. [Undergraduate first year]

\footnotetext{
75 With the recent changes in the law degree, this has changed once again.

76 Durkheim's sense of normlessness. Durkheim Suicid:; Marks 1974 Am J Sociol 329363.
} 


\begin{abstract}
There's a big difference from high school where you are still spoon-fed. It was like a big transition... the workload is also too much but we're, I am coping. [Undergraduate first year]

I was going to do a BSc, so like in high school leading up to 'varsity you get prepared, you do science and biology... with law there is no preparation. [Undergraduate first year]

So as time goes on you can see the generation gap and that it will be easier for people who come in now. I really, really struggled because I didn't have this background knowledge. [Undergraduate first year]
\end{abstract}

The respondents also drew attention to the fact that exams in law school demanded a higher level of understanding. This was because university exams, particularly those in law, they said, were structured differently, with exam questions being open-ended, calling for more factual and practical problem-solving skills. The respondents said that to answer these questions they needed to think, apply and understand their knowledge. It was not enough to learn by rote or know a theory in detail. Thus several of the respondents acknowledged that passing exams in the law school demanded a deeper level of understanding and the ability to apply theory rather than to regurgitate it. Many students had come to this realisation after writing and receiving their results for the June exam. As two student participants stated:

It's very different in high school, you get a question, you answer the question, whereas here it's more of an open window question... It's not like, what is the boy's name then you get your marks, you actually have to know your work. [Undergraduate first year]

Here it's more about application and understanding... I didn't back up my answers. I thought you just take out the theory from the book, like this is customary law because of this, and I didn't back it up with any case nothing and I found myself on the borderline of failing. [Undergraduate first year]

A further challenge, highlighted by the respondents, related to writing academic essays - especially legal essays. All respondents spoke of the different levels of expectation between school and university, particularly with respect to quality and quantity. They said that these differences related to both the "size of the essay" as well as the "type of essay". In this context, respondents also mentioned the emphasis by law lecturers on appropriate referencing and the need to use legal or academic authorities in their writing. The respondents said that in school a more creative style of writing was encouraged, where students were able to voice their own opinion without focussing on citing or quoting resources properly:

A big difference in essays at school that were 350 words maximum and in school it was creative essay writing and you make up a lot of hogwash, now you have to look for books and find actual information. [Undergraduate first year] 


\subsection{Uncertainty with respect to identity (identity crisis)}

The focus group discussion revealed that in addition to the uncertainties confronted at an academic level, students were faced with uncertainties at a psycho-social level. Many spoke of undergoing a crisis of identity or feeling like an outsider on entering university and the law school. They pointed out that it was a struggle adjusting to the anonymity at the university after the recognition experienced within a high school environment. The respondents said that at high school they were known and knew their peers and teachers personally. As a result, any academic or sporting achievements were acknowledged in a more personal way, whereas at university, they said, such achievements would not be noticed to the same extent by lecturers and peers. On a social level there was a perception that no one really knew who you were at university because you were just part of a larger community, a number amongst many. A few said they felt like a "small fish in a big pond" or "just a number" and that their previous achievements at high school, such as being popular, a prefect or head girl, were irrelevant at university. This sense of anonymity and loss was also reflected in the responses to the question, "do you interact socially on campus?"77 $35 \%$ of the students in family law indicated that they were not interacting on campus at a social level and many were not utilising, or were unaware of, the existing support structures. Two undergraduate first year students said:

[i]t is a big place and it is easy to get lost. [Undergraduate first year] [t]hen you come to Wits and you just a number... no one knows you and no one can do special favours for you... even if you did stand out academically its almost insignificant. [Undergraduate first year]

\subsection{Support system}

Students were asked a series of questions related to their knowledge and use of existing structures of support on campus and in the law school. It is understandable that students entering law school, for the first time, will experience periods of uncertainty and alienation, therefore needing some level of support. This becomes a particular concern when a student first enters university, coupled with the fact that she or he may be a firstgeneration student (figure 4). In such circumstances these students cannot draw on the experiences of parents or family members. Out of the 310 student respondents $23 \%$ indicated that they were first-generation students with no-one in their family having attended university before them. An undergraduate student in her first year said that:

77 Pre-questionnaire. 
Most people are reluctant to admit that they are not finding it as easy as they thought it was. [Undergraduate first year]

In the focus group the sample consisted of a combination of students who had family members with degrees and those without, undergraduate and post-graduate. In the discussion the respondents spoke about their experiences in orientation week, also mentioning the student mentorship programme. ${ }^{78}$ When talking about orientation week the majority agreed that more consistent support was required. Many said that they had met with a mentor in the beginning of the year but the mentorship had not been sustained. Some respondents appreciated that mentorship was not entirely a one-sided relationship and that all students needed to take responsibility for their own development as well:

\begin{abstract}
Mentors come up but nothing happens... Instead of orientation once-off they should keep going throughout the year... and keep checking up on first years. [Undergraduate first year]

Orientation week was successful... It's a foundation to make friends, show you around and helps you to know where to go. [Undergraduate first year]

You should go to orientation because you can learn a lot... you should also realize that the business world is not going to hold your hand, so swallow your pride and ask for help as opposed to waiting. [Undergraduate first year]
\end{abstract}

Some respondents also mentioned the type of help offered by the Centre for Counseling and Development (CCDU), highlighting that the unit was very helpful when addressing their stress and in assisting with their transition into law school. As one undergraduate student said:

[b]ut we also have the CCDU they have the brain development programmes and stuff if you have stress. I think the University is making an effort to try and meet students halfway... it's our responsibility also. [Undergraduate first year]

Another important aspect of support at University is the support students receive from one another. Although many of the respondents spoke about making new friends early in the term, only a few mentioned that these friends formed an important support system:

Like you make friends then you find that friendship does not work so you move on and make another friend that suits your personality and your interests... you know it's important to find a friend. [Undergraduate first year]

I think it is important to find a friend especially at varsity because you need a support group, especially if you need help in certain areas. [Postgraduate student]

78 There are a variety of support programmes in the Law School (Writing Centre, Law Student Council mentors) and the University Centre for Counselling and Development Unit (CCDU) Road to Success. 


\subsubsection{Postgraduate students}

Some of the students in the 21-25 and 26-50 age groups were completing a postgraduate 3-year degree and their transition was from an undergraduate non-law background into an intensive 3-year postgraduate law degree. ${ }^{79}$ As respondents in the focus group discussion, they said they had experienced uncertainty with respect to their transition from a non-legal degree into a legal degree at an academic level. It was noted, with this group that they felt less at a loss with respect to support within the law school, as the majority said they were able to cope.

For most of the postgraduate respondents the uncertainty they experienced related to feeling unprepared for the change in discourse, as legal discourse is unique in a variety of ways, such as the style of writing, referencing, analysis and argument. Most of this group of respondents said that there was an assumption made by lecturers in the law school that second-year students had the necessary skills to cope with second-year law subjects, particularly with respect to reading cases and legal referencing. In reality the respondents had not completed the foundational courses for law prior to entering the second year. This meant that as postgraduate students they needed to complete the first-year and the second-year law courses simultaneously. ${ }^{80}$ These students were registered for first-year courses such as Introduction to Law, Law of Persons, and Family Law together with second-year courses such as Law of Delict and Contract. Many said they were really struggling to catch up, and in this regard Family Law was identified as a very helpful course. The respondents said that it provided them with the foundational support they needed as it developed specific skills such as finding legal resources, referencing and writing legal essays. Two postgraduate students highlighted the difficulties they had encountered on entering law school in the second year:

What I found really difficult was the minute you get into second year... they start rattling away about the stuff you have to do, the cases... I found it really difficult because the others were at an advantage because they had started from proper first year. They were given the foundations. [Postgraduate student]

I think there is a gap because people have been in first year for an entire year... When they answer questions they have all those basic foundations... Whereas with us we are still learning these foundations. [Postgraduate student]

$7917 \%$ of the postgraduate group are between the ages $21-24$ years, $10 \%$ of the group are $25-50$ years of age.

80 The final LLB review report spoke of the need to address the "logical sequencing of modules and of ascending levels of competency". CHE National Review of LLB Programme 6. 
A further concern raised by certain postgraduate students was that their undergraduate courses were not valued in law. These respondents said they felt that the skills acquired whilst doing a BA or BCom were not regarded as important or necessary. This created the perception that their previous learning experience was irrelevant and that they had to start all over again. The devaluing of postgraduate students' prior learning could impact negatively on the student's self-worth and on the overall objective of "developing a holistic, independent thinker" as expressed in the HEQF and in the law school's revised curriculum statement. ${ }^{81}$ The law school needs to consider ways in which prior learning adds to and encourages the deepening of student learning. Consideration must also be directed toward aligning courses, skills-based and substantive, in such a way that the various levels and stages of intellectual growth are appropriately addressed.

\subsubsection{Theme 2: Skills for law}

The respondents, postgraduate and undergraduate, were asked about the type of skills and their development needed for law, with attention focused specifically on the Family Law course. Most respondents held the view that such skills-based courses were of value because they not only taught legal skills but also developed research and writing skills. A small number of them said that in their opinion learning skills at a university level was irrelevant and that such learning should take place in professional practice. One postgraduate student stated that:

I heard about the new curriculum, not sure that skills are really what they should be working toward. It's not about finding legislation but understanding and interpreting legislation. [Postgraduate student]

Nonetheless most said that the Family Law course was unique in the way it taught both legal skills and principles in a full year course. Some of the respondents went so far as to say that other law courses should model their structure on the Family Law course:

The activities give you an idea of what to expect in the exam and tutorials boost your confidence in that kind of way... I think all other courses should follow family law. [Undergraduate first year]

Family Law has the best skills including reading cases and how to find it (resources) electronically, in the library and where to find certain articles and how to search certain things. Actually they give us what we need for every other subject. [Undergraduate first year]

81 The revised statement is that a fundamental aim of the skills curriculum is to teach students to teach themselves. 
[p]ractical skills...if we don't have them with no legal background they must be taught. My research skills have improved, I can apply skills between courses as well. [Undergraduate first year]

With respect to teaching specific skills, respondents identified some of the skills they became aware of through the Family Law course. Most mentioned the development of their writing and referencing skills with many highlighting the fear they had with respect to plagiarism at university level. Some respondents also noted that, specifically in first year, plagiarism was viewed as alien to the ethos of the law school. Nearly all respondents pointed out that these skills were very different from those learnt either at school or during their undergraduate studies:

I found referencing a bit more difficult and the issue of plagiarism, I was so stressed. It's like a serious offence... but in high school you can even forge your referencing... that's what we used to do, 'cos you just find a way to manipulate your references. [Undergraduate first year]

\footnotetext{
Also the bibliography, you just make up books you put them in there... because nobody takes it seriously and the teacher doesn't go look. [Undergraduate first year]

I think referencing is an issue right up until fourth year... it is like a constant issue. [Post-graduate student]
}

In addition to learning new skills with respect to writing and referencing, the respondents also spoke of being surprised that numeracy was a skill required in law. Many said that when they chose to study law they thought it would involve a lot of reading but did not think it would involve any maths. In Family Law students are required to calculate marital property regimes, and they said that it was not always easy for them. Another skill mentioned related to a tool students were advised to use when answering legal questions. Students doing foundational courses, such as Introduction to Law, were introduced to the Issue, Principle, Application and Conclusion (IPAC)-procedure. Many said that they were uncertain, even confused, about the use of IPAC. Some respondents said that lecturers often contradicted one another, with some lecturers emphasising the use of IPAC when answering legal problems, whilst others described it "simply as an aid". This confusion highlights the importance of following a process of shared meaning and collaboration across the board in the law school.

It also highlights the importance of understanding the level at which a firstyear student (and some in subsequent years) may learn and acquire information, especially from lectures or tutorials. Many students at this level believe there is one correct answer, and that lecturers, who are perceived as experts, should provide the correct information, directly, without 
confusing students. ${ }^{82}$ Discrepancies that occur could therefore unsettle this perception, resulting in students viewing the lecturer as incompetent or as playing games ${ }^{83}$ — a situation suggested by comments raised in focus group discussions:

To learn how... to cohesively structure my writing... my lecturer helped me to see IPAC structure doesn't need to be used (rigidly). [Undergraduate first year] We were told not to do IPAC... so we see the different teachers contradict each other. [Postgraduate student]

What this calls for is an awareness of the nature of student learning, showing consistency and support across and within various subject areas - particularly when focussing on how we teach skills and how we support one another when teaching skills.

A further skill, viewed as an important component of a skills-based approach, is the inclusion of group work. In developing the skills focus in the law school the perception existed that an outcomes-based education system would expose students to peer-learning and group work. This same approach was then encouraged in several of the skills-based courses. ${ }^{84}$ In the focus group discussion most respondents said that they did not enjoy working in groups, yet they did enjoy participating in lectures. ${ }^{85}$ Some respondents said that they did not want to be confused by the input of their peers, preferring to rely on their own understanding of the subject or on lecturer input. These students were sceptical about the value of group work, stating that class time could be better spent hearing from the lecturer, as the expert. Such a response indicates that students view their peers as lacking the authority to provide correct answers and believe that their peers probably know as little as or even less than themselves. ${ }^{86}$ They also expressed discomfort about being subjected to too many viewpoints, as they thought this might confuse them, as highlighted in the following comments:

It's like scary because I will hate to get confused or be misled or misinformed so I am very cautious about groups, on the other hand if someone asked me to help them I would. [Undergraduate first year]

82 Felder and Brent speak of students entering college in a state of "ignorant certainty". At this level, beliefs are clear, based on what they have been told by others such as parents, peers, teachers. Over time this may shift to students taking more responsibility for their learning. Fedler and Brent $2004 \mathrm{~J}$ Eng Educ 269-277.

83 Students at this level do not appreciate or respond well to "game playing".

84 In Family Law there was an emphasis on group work in some class activities.

85 Felder says individuals at lower levels use dialogue to advance their own ideas without paying much attention to what others are saying. Fedler and Brent $2004 \mathrm{~J}$ Eng Educ 269-277.

86 Lecturers noted that when fellow students responded to questions during lectures their peers would often talk over them, ignoring their input. 
A group is distracting it is better to ask the professor... The professor will not confuse me. [Undergraduate first year]

I can't work in a group... when I know my work very well and someone is sort of borderline and will start confusing me. [Undergraduate first year]

\subsubsection{Theme 3: Perceptions and attitudes toward the course}

\subsubsection{Student responses}

In the pre-questionnaire students were asked what their expectations of the Family Law course were. A large number (130) said that their expectation was to learn and understand the law relating to Family Law. $64 \%$ of this group said they wished to learn the law, without elaborating further. Very few said they wished to increase their skills, their competence, or their ability to analyse and solve problems in family law. This finding was also supported in their responses to the question asking what they expected to gain from lectures. The majority (111) said they wanted to gain knowledge from lectures, without explaining what this encompassed. The next biggest group (90) said that they wanted to get clarification and understanding of the law. A small minority (30) said that they wished to acquire skills in reading and analysing legal problems particularly in family law.

The students also displayed a relatively shallow approach to learning in their responses to the question "What are your expectations of yourself in the course?" The majority (147) said they had an expectation to pass or to do well. A quarter of this group specifically said they expected a first for the course or that they intended to excel in the subject, without elaborating further. Their focus was chiefly on what they, as law students, needed to do in order to get good grades, and they showed little to no interest in developing a deeper understanding of family law. ${ }^{87}$ Approximately half the student respondents (75) said they expected to gain an understanding of the principles and relationships that form part of family law. Only 24 respondents said they hoped to gain competence in this area of law.

In both questionnaires the students were given an opportunity for selfevaluation. They were asked to identify a variety of factors contributing to their success and to identify what a good student should do to succeed. The majority of the answers given indicated that the students were of the opinion

87 We are not saying this thinking is inherently wrong but we are saying that an integral aspect of the curriculum shift lay in the development of a self-reflective, independent learner. There is a concern that if lecturers adopt an expert role, without utilising an integrative learning approach where independent thinking is encouraged, then we will fail in our intended objectives. An example would be where students are continually assessed on how well they replicate information and are not challenged intellectually. This would mean that we were encouraging rote learning and a shallow approach to academic development. 
that good lecture notes (361) and the lecturer (350) contributed to their success. Other key factors listed as contributing to their success were tutorials (337) and the use of the library (328). In response to question (ii) the majority of the students indicated that a good student should ask questions in class (195), debate issues actively with the lecturer and other students (167) and write extensive notes in lectures (148).

Student respondents showed their dependence on lecturers when asked, "What do students expect from their lecturers in the course?" The primary expectations that respondents listed were that lecturers should provide students with detailed hand-outs and notes (82\%), and lecturers should illustrate legal principles through the use of real stories (83\%). This once again ties in with a growing trend, throughout this study, for students to rely on their lecturers.

In addition to skills development, the revised law curriculum focuses on developing independent, self-reflective graduates. In the responses to the pre- and post-questionnaires and in the focus group discussions the student comments indicated a strong reliance on their lecturers for input, notes and support. They displayed less emphasis on their own work and taking responsibility for their own learning and growth. ${ }^{88}$ This replicates the state of "ignorant certainty" spoken about by Kroll or the pre-reflective, quasireflective stage of development highlighted by King and Kitchener. ${ }^{89}$ At this level of intellectual development students are generally of the view that the lecturer's role is to know the truth and to pass it on. The role of students is to absorb and replicate all they are told. ${ }^{90}$ Felder and Brent say that to encourage the students' intellectual development instructors need to accommodate the diversity within the student body whilst at the same time challenging students' beliefs about knowledge, the role of authorities, and the procedures that should be used to make judgments. ${ }^{91}$

Following the June examination period the students were asked to indicate the percentage they had achieved in an exam made up of problem-type questions. This would be the first time the students had writtten an exam in the course. Of the 208 responses to this question, (many left this question

88 This trend was also identified in lecturers' anecdotal feedback and student evaluations. Students indicated a preference for lecturers who provided worksheets and detailed notes as opposed to lecturers who encouraged self-study and selfreflection.

89 King and Kitchener Developing Reflective Judgment.

90 Kroll Teaching Hearts and Minds 93; Fedler and Brent $2004 \mathrm{~J}$ Eng Educ 269. King and Kitchener speak of stages and levels of reflective judgement. They state that students at undergraduate level, show a level of reasoning which is "pre-reflective" or "quasi-reflective". King and Kitchener Developing Reflective Judgment.

91 Fedler and Brent 2004 J Eng Educ 276. In Amanda Barratt's review of the Family Law course, under skills development, she expressed enthusiasm for participatory learning but asked "will they come?". Subsection 3 of Barratt Thoughts on Family Law. 
blank), $21 \%$ said they scored $70 \%$ and above. $25 \%$ said they got between $60-70 \%, 15 \%$ said they got between $55-60 \%$ and a large percentage (43\%) said they got below 55\%. ${ }^{92}$ This correlates with the results recorded for that period from the school of law. Of a class of 670 students, a small percentage (14.3\%) received $70 \%$ and above and $49.2 \%$ received $50-70 \%$. The pass rate for the June exam was $63 \%$. At the end of the year students were then expected to write a take-home exam that focussed specifically on examining all the skills attained during the year. The overall marks of the students improved, with a pass rate of $84.6 \%$.

\subsubsection{Lecturer responses}

The lecturer interviews focused on three broad issues, the lecturers' general attitude and experiences toward: 1) curriculum change in the law school; 2) change in the course itself; and 3) how they perceived the students in the course.

\subsection{Curriculum change in the law school}

The lecturer interviews revealed that, although most lecturers favoured the introduction of skills-based courses, the way in which the changes had been introduced was cause for concern, although not all of the lecturers interviewed were uncomfortable with the process. One of the interviewees was new to Wits and could comment only on the recent process in which she was involved - which she said was inclusive. Two other lecturers disagreed that the initial process of change was inclusive. It was felt that when the changes were introduced, communication was minimal across the school, and lecturer buy-in was never clearly established. Much of the development and early implementation process appeared to be top-down in nature. This could have been as a result of time constraints and existing institutional practices. Two family law lecturers stated that:

There were a number of lecturers, at all levels, who could have and should have had an opportunity to provide their input in a safe, non-judgmental, facilitated environment. I really think our biggest mistake was not collaborating across all courses and making sure we were reinforcing teaching across the board by using existing and available resources. A missed opportunity. [Lecturer B]

I think it was a great idea to integrate the skills courses because the concern was maybe that it would not work the way you want it to work. ...what happened was that the courses that were seen as the skills courses, you had to create the skills and integrate them with your curriculum. [Lecturer A]

All sorts of plans were put forward and we were left to make it up as we went along. No discussion. You will do this, your courses will no longer run and now 
this is your course. It felt personal, arbitrary and rather hierarchical. [Lecturer B]

A further concern mentioned by an interviewee was the failure to recognise the previous experience of some lecturers and the lack of experience of others. This related to both their skills and their expertise in particular subject areas. Furthermore, many of the initial discussions and ideas identified in planning documents were later forgotten or discarded. Some lecturers said it felt as if they were left to sink or swim when developing their skills courses. In addition lecturers displayed different levels of understanding and interest with respect to the students' intellectual development. In the interview some lecturers pointed out that when skillsbased courses were introduced no real support or structures were put in place. This meant that the lecturers were not provided with the necessary guidance or training on the integration or utilisation of skills in selected courses. Another issue raised was that when new lecturers came on board the continuation of the skills in identified courses could not be assured. These concerns are highlighted in the following comments:

I felt that we had no support in terms of teaching skills, we had no workshops, we had no skills development workshop. Basically you did it on your own as Family Law lecturers. We all did it on our own. [Lecturer A]

We had no workshop or discussion about the approach to be adopted... I taught skills based on what I had learnt over the years beforehand... Most of my previous training focused on skills training for adults but no-one asked me for my input. [Lecturer B]

For me a big thing was the fact that we as lecturers never spoke in a group about the skills we should or can focus on... I believe that some of the skills focussed on in first year are too much to absorb in first year and should at least be repeated in successive years. I also think skills are viewed as an addon by many lecturers so not used properly. [Lecturer B]

\subsection{The Family Law course}

The Family Law lecturers were asked what they thought of the changes to the Family Law course. They said that the course itself was not bad and the transition was a fairly integrated and collaborative process. The lecturers in the course, four at the time, were involved in developing the first course outline. An external academic ${ }^{93}$ was also invited to assess the overall course and her feedback was overwhelmingly positive. Each lecturer worked on a section and had to select various activities that incorporated the specific skill set required. The lecturers were very positive in their feedback on the process. They were also positive with respect to teaching the course, for the most part. What was pointed out was that there were

93 Amanda Barratt. 
some challenges encountered in balancing the theory with the skills, but according to the external assessor's comments and the lecturers interviewed, the inclusion of skills in certain sections made perfect sense:

\begin{abstract}
I very much admire the use of interactive learning. Students should develop important skills through the activities and should also understand the core substance of the course better, because they have engaged in active rather than passive learning. [External assessor] ${ }^{94}$

The integration of skills into the course, like I said, felt rather forced at times, a bit like an add-on. But in other instances it was easy and worked particularly with black letter law and activities around different marital regimes. [Lecturer B]
\end{abstract}

The lecturers pointed out that, with the skills-based approach, lecture preparation took much longer than before. They also commented on the fact that it had changed their teaching style, with one lecturer stating that lectures needed to become more structured in order to incorporate the activities required:

I found that no matter how long you teach this course it still takes hours to prepare. This is because with adding skills I have an awareness that students need to see it integrating, even when it doesn't. This first year felt very experimental at times. There were lectures where it really worked and then others when it just did not work. [Lecturer B]

It definitely affected prep time doing the skills stuff, very different to when you normally just go into theory. [Lecturer A]

My lecture style certainly changed. ...my style in Family Law became more structured I would try to plan my lectures to fit the activities, although it was not always possible. [Lecturer B]

We had someone from outside assessing the course and how we were doing so to help in taking the course forward but also, well... like we walked back into our bad routines of doing things. [Lecturer A]

\title{
6.2.3.2.3 Perceptions of students by lecturers
}

The lecturers observed that the course had progressed well, with the students participating in the activities, although at times there was a need to adjust certain activities or rethink a teaching approach. ${ }^{95}$ One concern raised was that the students appeared to acquire specific skills during the

94 Barratt Thoughts on Family Law.

95 For students born into an age of technology and social media there is a need to reconsider one's teaching and learning approaches. Although the LLB review report recognised that the law school has a web-based platform for student use, it stated that the school needed to respond to the opportunities that information technology offers to teaching and learning. CHE National Review of LLB Programme 3. 
lectures yet when they handed in assignments or performed activities it became obvious that the skills had not been acquired:

For the finding of legislation and articles, a few of them found journal articles, accredited legal journals, but most of them just did a google search and they thought that was okay and we thought we had completed the section properly. Which means we thought they had covered the skills and yet (after seeing their assignments) they weren't using them. [Lecturer A]

One lecturer said that some students did not always attend class, particularly if the lecture was purely activity-based. It was also pointed out that the responsibility for skills and knowledge transfer was reciprocal, and students needed to take on more of this responsibility. Some lecturers noted that the Family Law course was more than "a course'; it provided something over and above content and skills:

I felt with the first-year students it just wasn't a course. There were also other things happening. I think it was about anxiety and writing exams, June exams. I think they also need to learn the consequences of plagiarism, I don't think they understand it. I think we need to do modelling. [Lecturer A]

So we see there is a problem somewhere along the line. I'm not sure but I think the students need to take responsibility for these consequences too... I think it's from both sides. [Lecturer A]

\section{Conclusion}

This research is grounded in the notion that change is multi-faceted and complex and that often, in the haste to be seen to change, innovators overlook the phenomenology of change. This calls for change innovators to acknowledge the fact that change impacts not only on the institution but also on people within the institution, on how they experience and perceive that change. Thus, the initiators of change need to understand the nature of change to appreciate that, for effective change, the views of all participants should be acknowledged. This means that both the lecturer and the student need to be regarded as integral parts of the overall process, particularly when planning for change. In order to ensure their buy-in, a process of shared meaning should take place. This also means that if individuals such as lecturers are responsible for implementing change there should be a consistent and integrated training process.

It is generally acknowledged that change introduces levels of stress and anxiety as a result of people moving from the known to unknown. ${ }^{96}$ The students experienced anxiety in the transition either from high school into University or from undergraduate studies to postgraduate studies. They also experienced uncertainty with respect to understanding and adapting to the 
acquisition and development of their own knowledge. Anxiety for the lecturers related to their occupational identity where the introduction of change caused several to question their prior accomplishments and existing knowledge. The study revealed that in adopting far-reaching curriculum change many participants experienced feelings of loss and uncertainty. Such feelings can result in forms of resistance to change which can have a detrimental impact on curriculum change, even when it is well-intended. ${ }^{97}$

Therefore any further curriculum change needs to account for the variable and often shifting factors related to the change process and the people involved in the change. Not factoring this into planning could exacerbate existing issues or introduce new challenges. In addition, without training or a process of induction, newly appointed lecturers will be unable to assimilate or appreciate the changed curriculum. It is vital to recognise this need for an on-going, collaborative and consistent approach to curriculum change if the development of reflective, self-aware graduates is seriously intended. In the study the Family Law course was cited as setting a standard against which a number of other law courses should be measured. This can be accredited to the adoption of an inclusive, coordinated approach that ensured lecturer buy-in, and this positive influence is seen in the students' responses. ${ }^{98}$ Nonetheless, the success of one course on its own does not reflect the overall success of the skills-based curriculum, a factor which therefore informs the next phase of this ongoing study.

The study reveals that in considering change, be it at an institutional or policy level, the participants themselves - who they are, where they come from - should never be disregarded. Ignoring people in the change can lead to a spectacular failure to reach an intended outcome.

\section{Bibliography}

\section{Literature}

Axam 2001 SAJHR

Axam T "A Model for Learning and Teaching: Rights and Responsibilities in the New Legal Order" 2001 SAJHR 404-420

Badat Challenges of Transformation

Badat $S$ The Challenges of Transformation in Higher Education and Training Institutions in South Africa (Development Bank of Southern Africa Midrand 2010)

97 Fullan New Meaning Of Educational Change 34-36.

98 The lecturers and the external reviewer were included in process. 
Barratt Thoughts on Family Law

Barratt A Thoughts on Family Law LAWS1013 (University of Witwatersrand Law School Johannesburg 2012)

Booysen Fees Must Fall

Booysen S (ed) Fees Must Fall: Student Revolt, Decolonisation and Governance in South Africa (Wits University Press Johannesburg 2016)

Campbell 2014 Stell LR

Campbell $\mathrm{J}$ "The Role of Law Faculties and Law Academics: Academic Education or Qualification for Practice?" 2014 Stell LR 15-33

CHE Higher Education Qualifications Sub-Frameworks

Council on Higher Education Higher Education Qualifications SubFrameworks Standards Statement (Council on Higher Education Pretoria 2015)

CHE National Review of LLB Programme

Council on Higher Education National Review of Bachelor of Law (LLB) Programme Final HEQC Report (Council on Higher Education Pretoria 2016-2017)

Church 1988 THRHR

Church J "Reflections of Legal Education" 1988 THRHR 153-166

Colgan Perceptions of Democracy Education

Colgan D Perceptions of Democracy Education among Preset and Inset Students and Teacher Educators at a College of Education (MEddissertation University of Witwatersrand 2006)

DoE Curriculum 2005

Department of Education Curriculum 2005: Learning for the 21st Century (Department of Education Pretoria 1997)

DoE Green Paper

Department of Education Green Paper on Higher Education Transformation (Department of Education Pretoria 1996)

DoE Revised National Curriculum Statement

Department of Education Revised National Curriculum Statement (Department of Education Pretoria 2008)

Durkheim Suicide

Durkheim E Suicide: A Study in Sociology (Free Press New York 1951)

Fedler and Brent $2004 \mathrm{~J}$ Eng Educ

Fedler R and Brent R "The Intellectual Development of Science and Engineering Students Part 1. Models and Challenge" 2004 J Eng Educ 269277 
Fullan New Meaning of Educational Change

Fullan M The New Meaning of Educational Change $2^{\text {nd }}$ ed (Teachers College Press New York 1991)

Godfrey "Law Professionals"

Godfrey S "Law Professionals" in Erasmus J and Breier M (eds) Skills Shortages in South Africa: Case Studies of Key Professions (Human Sciences Research Council Pretoria 2009) 152-176

Greenbaum 2012 De Jure

Greenbaum L "Experiencing the South African Undergraduate Law Curriculum" 2012 De Jure 104-124

Hall and Loucks Innovation Configurations

Hall GF and Loucks SF Innovation Configurations: Analyzing the Adaptations of Innovations (University of Texas Austin 1978)

Hargreaves 2005 Teaching and Teacher Education

Hargreaves A "Educational Change takes Ages: Life, Career and Generational Factors in Teachers' Emotional Responses to Educational Change" 2005 Teaching and Teacher Education 967-983

James "Psychodynamics of Educational Change"

James C "The Psychodynamics of Educational Change" in Hargreaves A et al (eds) Second International Handbook of Educational Change vol 23 (Springer Berlin 2009) 47-64

Jansen "Rethinking Education Policy-Making"

Jansen JD "Rethinking Education Policy-Making in South Africa: Symbols of Change, Signals of Conflict" in Kraak A and Young M (eds) Education in Retrospect: Policy and Implementation since 1990 (Human Sciences Research Council Pretoria 2001) 41-59

Kennedy $1982 \mathrm{~J}$ Legal Educ

Kennedy D "Legal Education and the Reproduction of Hierarchy" $1982 \mathrm{~J}$ Legal Educ 591-615

King "Involvement in Innovation"

King N "Involvement in Innovation: The Role of Identity" in Shavinina LV (ed) The International Handbook on Innovation (Elsevier Science Oxford 2003) 619-630

King and Kitchener Developing Reflective Judgment King PM and Kitchener KS Developing Reflective Judgment: Understanding and Promoting Intellectual Growth and Critical Thinking in Adolescents and Adults (Jossey-Bass San Francisco 1994) 
Kroll Teaching Hearts and Minds

Kroll BM Teaching Hearts and Minds: College Students Reflect on the Vietnam War in Literature (Southern Illinois University Press Carbondale IL 1992)

Marks 1974 Am J Sociol

Marks SR "Durkheim's Theory of Anomie" 1974 Am J Sociol 329-363

Marris Loss and Change

Marris P Loss and Change (Anchor Press New York 1975)

Merriam Qualitative Research

Merriam S Qualitative Research: A Guide to Design and Implementation $2^{\text {nd }}$ ed (John Wiley San Francisco 2009)

Morrison Management Theories

Morrison K Management Theories for Educational Change (Sage London 1998)

Mouton, Louw and Strydom 2012 IBERJ

Mouton N, Louw GP and Strydom GL "A Historical Analysis of the PostApartheid Dispensation Education in South Africa (1994-2011)" 2012 IBERJ 1211-1222

Pateman 1980 J Philos Educ

Pateman T "Can Schools Educate?" 1980 J Philos Educ 139-148

Senge Fifth Discipline

Senge $\mathrm{P}$ The Fifth Discipline: The Art and Practice of the Learning Organization (Random House London 1990)

Snyman-Van Deventer and Swanepoel 2013 Stell LR

Snyman-Van Deventer E and Swanepoel CF "Teaching South African Law Students (Legal) Writing" 2013 Stell LR 510-527

Sugrue Future of Educational Change

Sugrue C The Future of Educational Change: International Perspectives (Routledge London 2008)

Van der Merwe 2007 April De Rebus

Van der Merwe P "Editorial" 2007 April De Rebus 2

Wits Law School Memorandum 2010

Wits Law School Wits Law School Memorandum: Skills Training Introduction (University of Witwatersrand Law School Johannesburg 2010)

Wits Law School Memorandum 2011

Wits Law School Wits Law School Memorandum: Developing an Integrated Skills-Based Curriculum for the LLB Degree at the School of Law, University 
of the Witwatersrand (University of Witwatersrand Law School Johannesburg 2011)

\section{Legislation}

Constitution of the Republic of South Africa, 1996

Higher Education Act 101 of 1997

\section{Government publications}

Gen N 1196 in GG 18207 of 24 July 1997

GN 928 in GG 30353 of 5 October 2007

\section{Internet sources}

Dibetle 2007 https://mg.co.za/article/2007-11-14-quality-of-law-degreesquestioned

Dibetle M 2007 Quality of Law Degrees Questioned https://mg.co.za/article/2007-11-14-quality-of-law-degrees-questioned accessed 20 September 2016

Fruehwald 2013 http://ssrn.com/abstract=2243128

Freuhwald ES 2013 Teaching Law Students How to Become Metacognitive Thinkers http://ssrn.com/abstract=2243128 accessed 21 September 2016

Mbembe $2015 \mathrm{http}: / /$ wiser.wits.ac.za/content/achille-mbembe-decolonizing -knowledge-and-question-archive-12054

Mbembe A 2015 Decolonizing Knowledge and the Question of the Archive http://wiser.wits.ac.za/content/achille-mbembe-decolonizing-knowledgeand-question-archive-12054 accessed 22 September 2016

SAQA 2015 http://regqs.saqa.org.za/viewQualification.php?id=22993

South African Qualifications Authority 2015 Registered Qualification: Bachelor of Laws http://regqs.saqa.org.za/viewQualification.php?id=22993 accessed 11 August 2017

Thomaz 2010 http://www.engineeringnews.co.za/print-version/llb-degreeunder-review-2010-01-15

Thomaz C 2010 Nationwide Review of LLB Degree under Way http://www.engineeringnews.co.za/print-version/llb-degree-under-review2010-01-15 accessed 18 November 2016

\section{List of Abbreviations}
Am J Sociol
American Journal of Sociology
BA
Bachelor of Arts
BCom
Bachelor of Commerce 


$\begin{array}{ll}\text { C2005 } & \text { Curriculum 2005 } \\ \text { CCDU } & \text { Centre for Counseling and Development } \\ \text { CHE } & \text { Council on Higher Education } \\ \text { DoE } & \text { Department of Education } \\ \text { HEQF } & \text { Higher Education Qualifications Framework } \\ \text { IBERJ } & \text { International Business and Economics } \\ & \text { Research Journal } \\ \text { IEB } & \text { Independent Examinations Board } \\ \text { IPAC } & \text { issue, principle, application and conclusion } \\ \text { J Eng Educ } & \text { Journal of Engineering Education } \\ \text { J Philos Educ } & \text { Journal of Philosophy of Education } \\ \text { J Legal Educ } & \text { Journal of Legal Education } \\ \text { LLB } & \text { Bachelor of Law } \\ \text { RNCS } & \text { Revised National Curriculum Statement } \\ \text { RTA } & \text { research and teaching assistant } \\ \text { SALDA } & \text { South African Law Deans' Association } \\ \text { SAJHR } & \text { South African Journal on Human Rights } \\ \text { SAQA } & \text { South African Qualifications Authority } \\ \text { Stell LR } & \text { Stellenbosch Law Review } \\ \text { THRHR } & \text { Tydskrif vir Hedendaagse Romeins- } \\ & \text { Hollandse Reg } \\ \text { Wits } & \text { University of Witwatersrand }\end{array}$

